\title{
Amplificação do genoma de circovírus suíno tipo 2 (PCV2) por círculo rolante e produção de um clone viral*
}

\author{
DIOGENES DEZEN
}

\author{
Paulo Michel Roehe (Orientador - UFRGS)
}

O circovírus suíno tipo 2 (PCV2) é o principal agente envolvido na Síndrome Multissistêmica do Definhamento dos Suínos (SMDS). Na maioria dos países onde a suinocultura tem expressiva importância econômica, a SMDS vem causando sérios prejuízos. Com o objetivo de contribuir para a caracterização genética de isolados brasileiros de PCV2, duas amostras autóctones foram clonadas e seqüenciadas na íntegra. Para tanto, o genoma viral foi extraído de tecidos de animais com SMDS e amplificado pelo método denominado "amplificação em círculo rolante com múltiplos primers" (ACRMP). Ambas seqüências apresentaram 1.767 nucleotídeos e diferiram entre si em apenas um nucleotídeo. A análise filogenética destas duas sequiências mostrou maior identidade com o grupo (1A) formado por isolados holandeses, franceses e chineses. Um isolado brasileiro previamente sequenciado, de Minas Gerais, foi classificado em outro grupo e a sequiência diferiu em até 16 nucleotídeos em relação aos isolados do Rio Grande do Sul. Na etapa seguinte desses estudos, visando o futuro desenvolvimento de vacinas, um dos genomas aqui seqüenciados foi transfectado em células de testículo de suíno (ST). Antígenos virais nas células transfectadas foram detectados por imunoperoxidase, demonstrando assim a infecciosidade do clone produzido. Entretanto, o clone infeccioso obtido não foi capaz de multiplicar-se a ponto de fornecer massa antigênica que viabilizasse a produção de uma vacina. Em vista disso, realizou-se uma tentativa de criar uma linhagem celular persistentemente infectada. Para isso, o DNA de PCV2 foi novamente transfectado em células ST com um plasmídeo contendo o gene de resistência a geneticin, visando a seleção de colônias celulares resistentes. Após a transfecção, porém, observou-se um efeito negativo na formação de colônias resistentes a esta droga. Este efeito foi dose-dependente em relação à quantidade de DNA de PCV2, o que impossibilitou o estabelecimento de uma linhagem celular persistentemente infectada. Isto pode estar relacionado com a expressão da proteína da ORF3 que induz apoptose ou à indução de citocinas, como interferons, embora outros mecanismos não possam ser excluídos, como efeito tóxico do alto número de cópias de genomas de PCV2. Analisando os resultados obtidos durante a realização destes estudos, conclui-se que as amostras de PCV2 circulantes no Brasil apresentam de identidade alta (99,09\%).

Descritores: circovírus suíno tipo 2, SMDS, amplificação por círculo rolante.

*Dissertação de Mestrado n. 459 (Especialidade: Biologia Celular e Molecular). 73f. Programa de Pós-graduação em Ciências Veterinárias [www.ufrgs.br/ppgcv], Faculdade de Veterinária, Universidade Federal do Rio Grande do Sul (UFRGS), Porto Alegre, RS/Brasil. CORRESPONDÊNCIA: D. Dezen [ddezen@gmail.com]. 


\section{Rolling circle amplification of genomes of porcine circovirus type 2 (PCV2) and viral clone production**}

\section{DIOGENES DEZEN}

Paulo Michel Roehe (Adviser - UFRGS)

Committee: Ana Cláudia Franco (UFRGS), Cláudio Wageck Canal (UFRGS), Benito Guimarães de Brito (IPVDF)

Porcine circovirus type 2 is the main etiological agent implicated in the postweaning multisystemic wasting syndrome (PMWS) in pigs. In countries with considerable swine production, PMWS is a major cause of economic losses. In order to perfom a genetic analysis on Brazilian PCV2 isolates, two PCV2 isolates inform the state of Rio Grande do Sul - Brazil, were cloned and fully sequenced. Viral genomes were extracted from tissues of animals with PMWS and amplified using multiplyprimed rolling circle amplification (MPRCA). Both PCV2 sequences were 1,767 nucleotides long and differed in only one nucleotide from each other. Phylogenetic analysis of both sequences showed the highest sequence identity with a group of viruses (group 1A) that also harbors many Dutch, French and Chinese isolates. This suggests that the Brazilian PCV2 isolates examineed here might have been imported from one of such countries. Interestingly, a Brazilian isolate from Minas Gerais previously sequenced by others, was observed to belong to another group of PCV2 isolates and differs at 16 different sites from the isolates from Rio Grande do Sul. In order to develop a vaccine, one of the isolates here sequenced was transfected into swine testis (ST) cells. Viral antigens were detected in the transfected ST cells by immunoperoxidase, indicating that such PCV2 clone could give rise to infectious virus. However, the cloned virus was not able to multiply to high titers, what would be a major drawback in vaccine development. In attempting to solve this problem, the development of a PCV2- persistently infected cell line was targeted. PCV2 DNA was cotransfected with a plasmid carrying the geneticin resistance gene in order to allow clone selection by identification of geneticin resistant cells. However, the PCV2 DNA had a negative effect on the number of geneticin resistant colonies. Interestingly, this negative effect of PCV2 DNA was dose dependent and for this reason, it was not possible to establishing a persistently infected cell line. This might be linked to ORF3 protein expression, which induces apoptosis or production of interferon. Analyzing the results obtained in this study, the Brazilian PCV2 isolates had high identity (99.05\%).

Key words: porcine circovirus type 2, PMWS, rolling circle amplification.

Presented: 26 February 2007

\footnotetext{
**Master's Thesis \# 459 (Field: Cellular and Molecular Biology). 73p. Graduate Program in Veterinary Sciences [www.ufrgs.br/ppgcv], Faculdade de Veterinária, Universidade Federal do Rio Grande do Sul (UFRGS), Porto Alegre, RS/Brazil. CORRESPONDÊNCIA: D. Dezen [ddezen@gmail.com].
} 